ACTA AGROBOTANICA

Vol. 59, z. 12006

s. 521528

\title{
The harmfulness of Aphis fabae Scop. feeding on the flowers of park rose (Rosa sp.)
}

\author{
BOŻENNA JAŚKIEWICZ \\ Department of Entomology, University of Agriculture, ul. Leszczyńskiego 7, \\ 20069 Lublin, Poland
}

(Received: 9.05.2005)

\section{S u m m ary}

The studies were conducted in the years 19992001 in the green area of the Lublin city in the street (A) and park (B) sites. The purpose of the studies was to determine the dynamics of the bean aphid population (Aphis fabae Scop.) and the effect of its feeding on the blooming of park roses (Rosa sp.). The presence of dwarf specimens of $A$. fabae was observed only on the crown petals and the sepals. Their feeding significantly affected the decorative character of roses, since the crown petals inhabited by them were faster to dry out and fall down. The presence of aphids on the shrubs was found throughout the period of about two months, and the aphids were more numerous in the street site.

Key words: Aphis fabae Scop., park rose, harmfulness

\section{INTRODUCTION}

Roses as decorative plants are known in the whole world. Their decorative character is influenced by the beautiful flowers, fruit, effective leaves and the plant habit (B u g a ł a , 1991). They are planted in parks, gardens, lawns and squares singularly or in small groups in the form of hedges and in rows. They are found along the communication tracts, on the railway embankments and in the ditches ( $\mathrm{J}$ a ś ki e w ic z et al., 2001).

Roses are inhabited by numerous pests, including for example moths from the family Tortricidae, hymenoptera from the family Tenthredinidae, Argidae and Cynipidae, as well as numerous aphid species. One of the aphids occurring on roses is Aphis fabae Scop., which also feeds on other plants from various botanical families 
( $\mathrm{S}$ z e l ę g i e w i c z, 1968). In a warmer climate, it can also feed on roses, negatively affecting their blooming (J a śki e w i c z and K mi éc, in print).

The purpose of the present paper was to determine the population dynamics of Aphis fabae Scop. and the effect of their feeding on the blooming of park roses (Rosa sp.) in the green area of Lublin.

\section{MATERIAL AND METHODS}

The studies were conducted on the shrubs of park roses (Rosa sp.) in the years 1999 2001. The monitoring of plants was performed in two sites: a street one (A green area in front of the Rector's Office of the Agricultural University) and a park one (B the Museum of the Lublin Countryside). Five shrubs growing close to each other were selected in each site. The winged and wingless aphids (including the larvae) were counted on each plant on five shoots of similar length. The observation was carried out in 10-days' intervals, beginning with early spring and finishing in late autumn, after the leaves had fallen down. The examined shrubs were not subjected to any chemical control.

The frequency index $(\mathrm{F})$ was determined, which shows the ratio of the number of samples where a given species occurred to the number of samples taken on a given plant, and it was calculated according to the formula:

$$
\mathrm{C}=\frac{q}{Q} * 100,
$$

where: $q$ number of trials when a given species was noted,

$Q$ number of all samples.

Four classes of constancy (frequency) were distinguished ( $\mathrm{G}$ ó r n y and G r ü m, 1981): euconstants (0.76-1), constants (0.51-0.75), accessory species (0.26-0.50), accidents $(\leq 0.25)$.

In order to determine the effect of the feeding of aphids on the content of photosynthetic pigments, total nitrogen and reducing sugars in the flower buds of roses, those parts were subjected to biochemical analysis. The content of photosynthetic pigments was marked according to the method by Lichternthaler and We 11 burn (Lichternthaler and Wellburn, 1983), the concentration of reducing sugars according to the method of Hadgedorn-Jensen, and the quantity of total nitrogen according to the method of Kjeldahl (K ł y s z e j k o-S t e f a n o w i c z , 1982).

The data referring to the course of the weather in the studied years were obtained from the Department of Agrometeorology of the Agricultural University of Lublin. 


\section{RESULTS}

As a result of studies conducted in the years 1999 - 2001, it was observed that dwarf (1.2 mm) specimens of Aphis fabae Scop. fed on the shrubs of park roses (Rosa sp.). Their presence was found only on the crown petals and sepals (Fig. 2,3).

Figure 1 presents the dynamics of the population of Aphis fabae Scop. in the street site (A) and the park site (B), table 1 contains the data concerning the course of the weather in the studied years, table 2 shows the dates of occurrence, number and frequency of aphids, while table 3 includes the results of biochemical analyses of the changes in the content of some elements in the flower buds of roses.

In 1999, after a frosty winter and cold spring, the first specimens of Aphis fabae Scop. on roses were observed in the second decade of June (Fig. 1). They colonized the studied plants for about a month (till the second decade of July). The maximum number was observed in the third decade of June, when the aphid number in this time
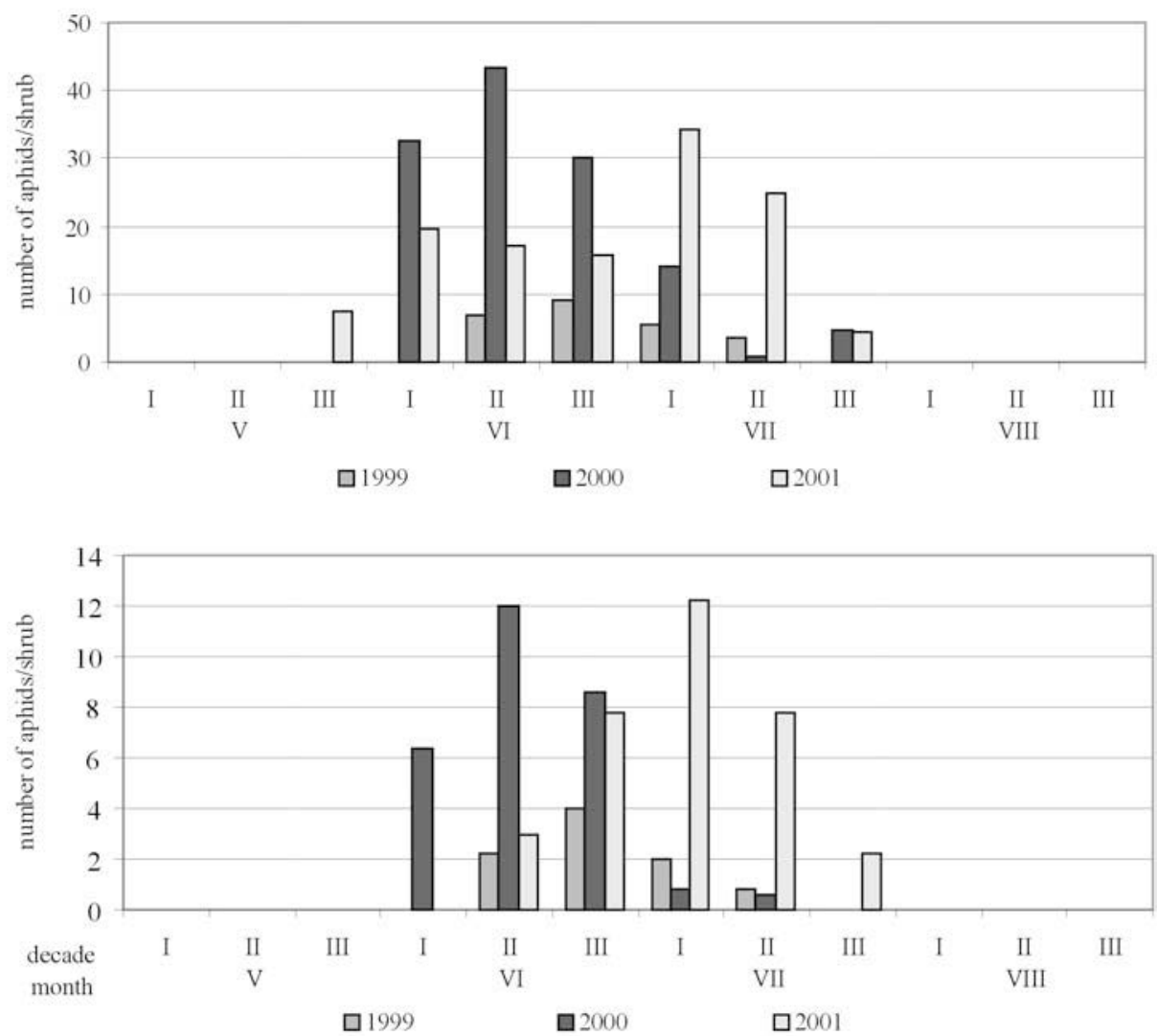

Fig. 1. The dynamics of Aphis fabae Scop. population on Rosa sp. in 19992001. 
Table 1

The general information about the weather conditions in Lublin in 19992001.

\begin{tabular}{|c|c|c|c|c|c|c|c|c|c|c|}
\hline \multirow{2}{*}{ Month } & \multirow{2}{*}{ Decade } & \multicolumn{3}{|c|}{ Temperature of the air $\left({ }^{\circ} \mathrm{C}\right)$} & \multicolumn{3}{|c|}{ Rainfalls (mm) } & \multicolumn{3}{|c|}{ Humidity (\%) } \\
\hline & & 1999 & 2000 & 2001 & 1999 & 2000 & 2001 & 1999 & 2000 & 2001 \\
\hline \multirow{3}{*}{ March } & I & 3.4 & 2.0 & 2.1 & 10.5 & 36.5 & 4.8 & 84.5 & 80.6 & 79.9 \\
\hline & II & 1.4 & -1.0 & 5.3 & 0.6 & 13.1 & 15.8 & 89.6 & 83.2 & 83.9 \\
\hline & III & 0.8 & 4.4 & -0.5 & 5.9 & 15.3 & 13.2 & 84.4 & 84 & 73 \\
\hline \multirow{3}{*}{ April } & I & 8.7 & 4.4 & 9.6 & 3.1 & 55.1 & 15 & 74.3 & 78.6 & 68.7 \\
\hline & II & 8 & 12.4 & 5.4 & 73 & 12.9 & 3.2 & 79.1 & 69.2 & 78.1 \\
\hline & III & 9.1 & 16.9 & 10.4 & 5.5 & 0 & 46.7 & 76.2 & 69.1 & 80.9 \\
\hline \multirow{3}{*}{ May } & I & 8.7 & 13.4 & 15.4 & 6.7 & 0 & 0 & 71.1 & 51.9 & 61.3 \\
\hline & II & 10 & 15.8 & 14.2 & 39.2 & 18.5 & 2.5 & 78.7 & 59.6 & 60.2 \\
\hline & III & 15.6 & 14.7 & 12.3 & 0 & 32.2 & 17.4 & 69.2 & 74.5 & 64 \\
\hline \multirow{3}{*}{ June } & I & 18.2 & 17.0 & 13.7 & 17.7 & 11.2 & 27.7 & 78.2 & 70.3 & 71.8 \\
\hline & II & 20.4 & 16.8 & 14.9 & 72.5 & 15.7 & 12.7 & 85.5 & 69,6 & 78.1 \\
\hline & III & 17.1 & 17.1 & 17.2 & 70.7 & 9.5 & 7.2 & 83.9 & 71.2 & 68.3 \\
\hline \multirow{3}{*}{ July } & I & 21.8 & 16.4 & 20.1 & 46.5 & 36.8 & 33.7 & 80.7 & 78.6 & 81.8 \\
\hline & II & 19.6 & 16.4 & 22.9 & 24.6 & 26.1 & 19.6 & 71.7 & 73.8 & 71.5 \\
\hline & III & 18.8 & 17.9 & 21.6 & 31 & 75.2 & 207.6 & 80.4 & 79.3 & 84.7 \\
\hline \multirow{3}{*}{ August } & I & 20 & 17.7 & 20.4 & 18 & 23.6 & 54.9 & 74.2 & 76.2 & 71.7 \\
\hline & II & 16.6 & 20.8 & 21.6 & 11.5 & 0.3 & 0 & 80.1 & 71.1 & 67.7 \\
\hline & III & 15.4 & 16.4 & 19.2 & 4 & 4.4 & 12.6 & 78.5 & 77.9 & 73.5 \\
\hline \multirow{3}{*}{ September } & I & 16.2 & 13.4 & 13.8 & 12.7 & 16.3 & 30 & 73.7 & 81.4 & 82.8 \\
\hline & II & 12.1 & 10.8 & 12.5 & 0 & 50.4 & 72.7 & 80.6 & 84.9 & 88.2 \\
\hline & III & 15.8 & 9.0 & 9,2 & 24.9 & 0 & 23.1 & 86.7 & 81.7 & 80.4 \\
\hline \multirow{3}{*}{ October } & I & 10.9 & 12.7 & 14.1 & 23.4 & 0 & 4.6 & 89.8 & 76.1 & 85.8 \\
\hline & II & 4.6 & 10.7 & 10.4 & 9.6 & 0 & 1.3 & 88.7 & 78.4 & 88.6 \\
\hline & III & 6.2 & 8.6 & 6.4 & 1.9 & 2.2 & 13.4 & 83.3 & 73.3 & 80.2 \\
\hline
\end{tabular}

Table 2

The occurrence of Aphis fabae Scop. on the Rosa sp. shrubs.

\begin{tabular}{|c|c|c|c|c|c|c|c|}
\hline Year & Site & $\begin{array}{c}\text { Appearance } \\
\text { of aphids }\end{array}$ & $\begin{array}{c}\text { Date of } \\
\text { max. }\end{array}$ & $\begin{array}{c}\text { Disappearance } \\
\text { of aphids }\end{array}$ & $\begin{array}{c}\text { Number of } \\
\text { aphids/shrub }\end{array}$ & $\begin{array}{c}\text { Total } \\
\text { number } \\
\text { in season }\end{array}$ & Frequency \\
\hline \multirow{2}{*}{1999} & A & II d. VI & III d. VI & III d. VII & 25.8 & 129 & 0.19 (accidents) \\
\cline { 2 - 8 } & B & II d. VI & III d. VI & III d. VII & 9.0 & 45 & 0.19 (accidents) \\
\hline \multirow{2}{*}{2000} & A & I d. VI & II d. VI & I d. VIII & 125.6 & 628 & 0.25 (accidents) \\
\cline { 2 - 8 } & B & I d. VI & II d. VI & III d. VII & 28.6 & 143 & 0.208 (accidents) \\
\hline \multirow{2}{*}{2001} & A & III d. V & I d. VII & I d. VIII & 124.2 & 621 & 0.292 (accessory species) \\
\cline { 2 - 8 } & B & II d. VI & I d. VII & I d. VIII & 33.4 & 167 & 0,208 (accidents) \\
\hline
\end{tabular}

Table 3

The influence of Aphis fabae Scop. feeding on the contents of some chemical components in floral buds of roses.

\begin{tabular}{|c|c|c|c|c|}
\hline \multirow{2}{*}{ Floral buds } & \multicolumn{4}{|c|}{ Contents } \\
\cline { 2 - 5 } & $\begin{array}{c}\text { Chlorophyll A+ B } \\
\text { (mg/g s.m.) }\end{array}$ & $\begin{array}{c}\text { Carotene +Xantophyl } \\
\text { (mg/g s.m.) }\end{array}$ & $\begin{array}{c}\text { Total nitrogen } \\
\text { (\% s.m.) }\end{array}$ & $\begin{array}{c}\text { Reducing sugars } \\
\text { (mg\%) }\end{array}$ \\
\hline Control & 0.37 & 0.06 & 2.97 & 48.5 \\
\hline Damaged & 0.40 & 0.06 & 2.21 & 66.5 \\
\hline
\end{tabular}




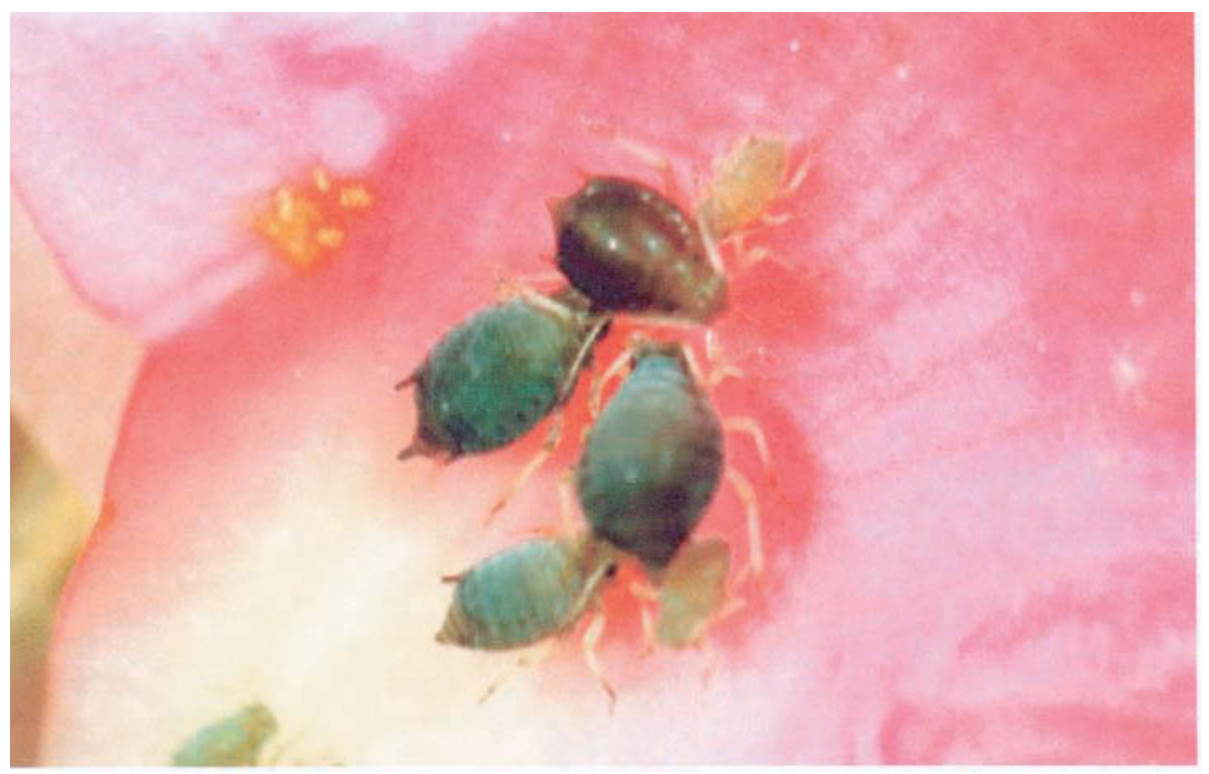

Fig. 2. Aphis fabae Scop. feeding on the crown petals of roses.

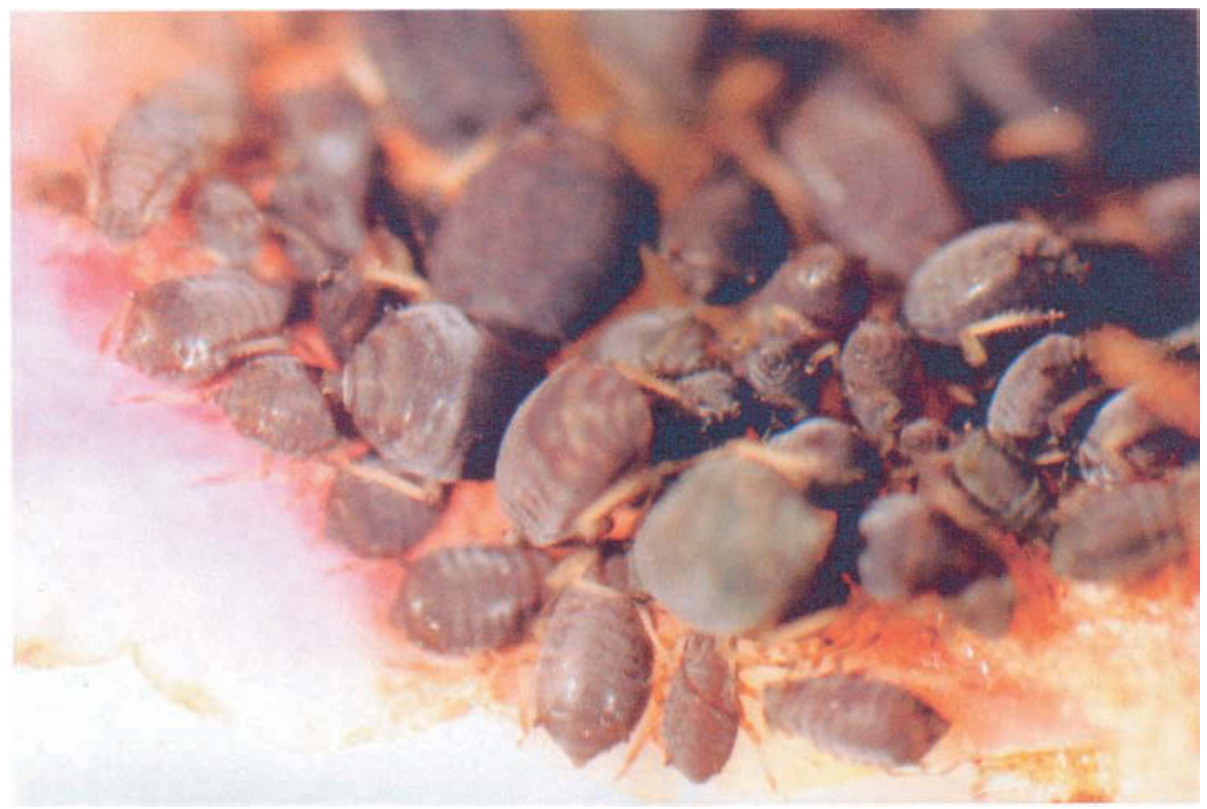

Fig. 3. Aphis fabae Scop. feeding on the crown petals of roses. 
was more than twice as big in site A 9.2 aphids/shrub as compared to site B 4.0 aphids/shrub.

In 2000, after a mild winter, the spring was very warm, and the presence of the first aphids in both sites was found already at the beginning of June. The maximum number was then observed in the second decade of that month. 43.4 aphids/shrub were found in site A, and 12.0 aphids/shrub in site B. The disappearance of aphids in site A took place during the first decade of August, while in site B in the third decade of July. The disappearance of aphids in that period was probably affected by numerous showers in July, which washed off the aphids from the rose flowers, causing great death rate.

In 2001, after a mild winter and an early period of vegetation, singular aphids were observed in site A in the third decade of May. They stayed with varying intensity till the end of the third decade of June, and the maximum number was found during the first decade of July 34.2 aphids/shrub. The disappearance of aphids in that site was found after about two months since their first occurrence, in the third decade of July. The first specimens of Aphis fabae Scop. in site B were observed in the second decade of June, and the maximum number was found like in site A during the first decade of July 12.2 aphids/shrub. The disappearance of aphids in site A was also noticed in the third decade of July.

In each studied year, a considerably greater number of aphids Aphis fabae Scop. was observed on roses in the street site (A) as compared to the park site (B) (Table 2 ). In site $A$ the aphids were most numerous in the year 2000 , their total number made up of 628 individuals, while in site B there were 167 individuals in the year 2001. Due to the occurrence of those aphids on plants at anthesis, they were included in IV or $\mathrm{V}$ frequency classes.

The feeding of aphids Aphis fabae Scop. had a considerable effect on the worse decorative character of roses, since their presence on the crown petals and the sepals caused that the petals dried out and fell down faster. Besides, the chemical analysis established that the content of chlorophyll A and B and reducing sugars increased on the damaged rose buds as compared to the control, while the content of carotene and xantophyl was the same and the content of total nitrogen went down (Table 3).

\section{DISCUSSION}

Aphis fabae Scop. is a heteroecious and holocyclic, a polyphagous species feeding on plants from various botanical families, especially on Polygonaceae, Chenopodiaceae and Solanaceae (S z e lęg i e w i c z, 1968). It causes the most serious injuries in the cultivations of beets ( $\mathrm{Ku} \mathrm{c} \mathrm{zak}, 1991)$ and also broad bean and faba bean (R e k ow s k a , 2001). The dwarf specimens of this species were observed on the examined shrubs of park roses and they fed only on the sepals and crown petals. The accessible literature lacks any data on the population dynamics and the feeding of this species on the rose flowers. It is only the author's own studies that showed that A. fabae increased the group of its host plants ( $\mathrm{Cichocka}$ and $\mathrm{J}$ a śkiewic $\mathrm{z}$, 2003; J a ś ki e w i c z , 2003; J a ś k i e w i c z and K m i éc, in print). The presence of 
aphids on the examined shrubs was observed throughout the period of about two months, and their highest number was found at the turn of June and July. A similar period of the occurrence of this species, but not of dwarf specimens, on the shrubs of Spiraea vanhouttei Zabel., Chaenomeles japonica Lindl. and Cotoneaster divaricatus Rehder et E.H. Wilson in the urban green areas is given by Jaśkiewicz (1997, 2004). The maximum number of $A$. fabae on roses ranged from 4.0 to 34.2 individuals/ shrub, depending on year and site. The bean aphids were more numerous on the shrubs of park roses in the street site as compared to the park site. This is confirmed by the results of studies of other authors (C i ch ocka and Goszczyńs ki, 1991; Jaś$\mathrm{kiew}$ i c z , 2003), pointing that greater air pollution and soil contamination is followed by increased populations of insects with the stinging-sucking mouth apparatus in the street site.

\section{CONCLUSIONS}

1. Aphis fabae Scop. fed only on the crown petals and sepals of park roses (Rosa sp.).

2. The aphids colonized the studied plants for about two months, and their maximum number was found at the end of June or at the beginning of July, depending on the year of studies.

3. The aphids were much more numerous to colonize the rose flowers in the street site as compared to the park site.

4. The feeding of aphids caused that the petals dried out and fell down faster and changes in their chemical composition were observed.

\section{REFERENCES}

B u g a ł a W., 1991: Drzewa i krzewy dla terenów zieleni. PWRiL, Warszawa, pp. 594.

Ci ch o c k a E., G o s z c z y ń s k i W., 1991: Mszyce zasiedlające drzewa przyuliczne w War szawie. W: Mszyce ich bionomia, szkodliwość i wrogowie naturalni (red. Cichocka E., Goszczyński W.), PAN, Warszawa, 918.

Cich ock a E., Jaśkie wicz B., 2003. Aphids inhabiting roses in diferent culture in 1967 2003. Aphids and Other Hemipterous Insects, Monograph, PAG, Rogów, 9, 1736.

G ó r n y M., G r ü m L., 1981: Metody stosowane w zoologii gleby. PWN, Warszawa, pp. 483. J a ś k i e w i c z B., 1997: Skład gatunkowy i dynamika pojawu mszyc na wybranych krzewach ozdobnych w latach 1973 1993. Rozprawa habilitacyjna. Wyd. Akad. Roln. Lublin s. Rozpr. Nauk. 183: 193.

J a śk i e w i c z B., 2003: The species composition and number of aphids on the shrubs of Pinus mugo Turra and Rosa sp. in urban condition. Elect. J. Pol. Agric. Univ. Ser. Horticult. 6, Issue 2, www.ejpau.media.pl

J a ś k i e w i c z B., 2004: Aphids (Homoptera, Aphidodea) inhabiting the shrubs of Cotoneaster divaricatus Rehder et E.H.Wilson in the urban green area of Lublin. Part I. The population dynamics. Elect. J. Pol. Agric. Univ. Ser. Horticult. 7, is. 2, www.ejpau.media.pl

J a śk i e w i c z B., K m i eć K. The harmfulness of aphid Aphis fabae Scop. occurring on roses in urban conditions. The Journal of Agrobiology and Ecology (in print). 
J aśk i ew i cz B., Gantner M., K mi eć K., B artos ze k A., 2001: Występowanie mio downicy różanej na krzewach róży dzikiej. Ochr. Rośl. 7/8, 1011.

Kły s zejk o Stefa n ow i c z L., 1982: Ćwiczenia z biochemii, PWN, Warszawa, pp. 400.

Li c h t e r n th a le r H. K., Wellburn A. R., 1983: Determination of total carotenoids and chloro phylls a and b of leaf extracts in different solvents. Bioch. Soc. Trans. 11, 591592.

Ł u c z a k I., 1991: Szkodliwość mszycy burakowej (Aphis fabae Scop. na buraku ćwikłowym. W: Mszyce ich bionomia, szkodliwość i wrogowie naturalni (red. Cichocka E., Gosz czyński W.), PAN, Warszawa, 3141.

R e k ow s k a D., 2001: Aphis fabae Scop. and its enemies on selected plant species. Aphids and Other Homopterous Insects, Siedlce, 8, 383394.

Szelęgiewicz H., 1968: Mszyce Aphidoidea. Katalog fauny Polski. XXI, 4, 316, PWN, Warszawa.

\section{Szkodliwość Aphis fabae Scop. żerującej na kwiatach róży parkowej (Rosa sp.)}

\section{Streszczenie}

Badania prowadzono w latach 1999-2001 na terenie zieleni miejskiej Lublina na stanowisku przyulicznym (A) i parkowym (B). Celem pracy było ustalenie dynamiki populacji mszycy burakowej (Aphis fabae Scop.) oraz wpływu jej żerowania na kwitnienie róż parkowych (Rosa sp.). Obecność karłowych osobników A. fabae notowano wyłącznie na płatkach korony i działkach kielicha. Ich żerowanie miało znaczny wpływ na obniżenie dekoracyjności róż, ponieważ zasiedlane przez nie płatki korony szybciej usychały i odpadały. Obecność mszyc na krzewach notowano przez okres około dwóch miesięcy, liczniej mszyce zasiedlały kwiaty róż na stanowisku przyulicznym. 